\title{
AGERATUM CONYZOIDES L. \\ (PEMANFAATAN SEBAGAI OBAT DAN BIOAKTIVITASNYA)
}

\author{
Marina Silalahi \\ marina.silalahi@uki.ac.id \\ Universitas Kristen Indonesia
}

\begin{abstract}
Ageratum conyzoides or badotan is a wild plants which uses as traditional medicine. This plant has a distinctive aroma similar to "the smell of goats" so it is called "goatweed". This article aims to explain the use of A. conyzoides as a drug and its bioactivity. The writing of this article is based on the study of literature obtained online and offline including various scientific articles then reviewed and synthesized so as to provide comprehensive information regarding the use of $A$. conyzoides as traditional medicine. In traditional medicine, Ageratum conyzoides is used as medicine for wounds, ulcers, and fever. Ageratum conyzoides have secondary metabolites such as terpenoids, flavonoids, steroids, terpenes, saponins, fatty acids, and alkaloids, with the main compounds stigmasterol and $\beta$-sitosterol. Bioactivity of $A$. conyzoides are antihistamine, antimicrobial, antiplasmodial, cytoprotective, analgesic, antioxidant and anti diabetes mellitus.
\end{abstract}

Keywords: Ageratum conyzoides, antimicrobial, $\beta$-sitosterol, cytoprotective, analgesic.

\section{ABSTRAK}

Ageratum conyzoides atau badotan merupakan salah satu tumbuhan liar yang banyak dimanfaatkan sebagai obat tradisional. Tumbuhan ini memiliki aroma khas mirip dengan "bau kambing" sehingga disebut juga sebagai "goatweed". Artikel ini bertujuan untuk menjelaskan pemanfaatan $A$. conyzoides sebagai obat dan bioaktivitasnya. Penulisan artikel ini didasarkan pada kajian literatur yang diperoleh secara online maupun offline meliputi berbagai artikel ilmiah kemudian dikaji dan disintesakan sehingga memberikan informasi yang kompehensif mengenai pemanfaatan $A$. conyzoides sebagai obat tradisional. Dalam pengobatan tradisional Ageratum conyzoides dimanfaatkan sebagai obat luka, bisul, dan demam. Ageratum conyzoides mengandung metabolit sekunder dari golongan terpenoid, flavonoid, steroid, terpen, senyawa, saponin, asam lemak, dan alkaloid, dengan senyawa utama stigmasterol dan $\beta$-sitosterol. Bioaktivitas yang 
Silalahi, Ageratum Conyzoides I. (Pemanfaatan sebagai Obat dan Bioaktivitasnya)

dimiliki oleh $A$. conyzoides antara lain sebagai anti histamin, antimikroba, antiplasmodial, sitoprotektif, analgesik, antioksidan dan anti diabetes mellitus.

Kata Kunci : Ageratum conyzoides, antimikroba, $\beta$-sitosterol, sitoprotektif, analgesik.

\section{PENDAHULUAN}

Pemanfaatan tumbuhan sebagai obat tradisonal maupun sebagai obat alternatif semakin diminati seiring meningkatnya paradigma untuk kembali ke bahan alam. Secara umum diyakini bahwa pemanfaatan tumbuhan sebagai obat relatif lebih aman dibandingkan dengan obat sintesis. Hal ini salah satu faktor yang mendorong penelitian tumbuhan obat semakin menarik untuk dikaji dari berbagai aspek. Metode yang dikembangkan untuk mengetahui khasiat tumbuhan studi etnomedisin atau etnobotani, bioessay, dan purifikasi senyawa bioaktif.

Peningkatan kebutuhan tumbuhan obat baik oleh industri farmasi maupun untuk kebutuhan sendiri juga terdeteksi dari lahirnya perdagangan tumbuhan obat baik tumbuhan hasil budidaya maupun tumbuhan liar. Kohler dan Baghdadi-Sabeti menyatakan bahwa pasar menjual tumbuhan obat sebesar $5-18 \%$ pertahun. Silalahi et al. (2015) melaporkan sebanyak 245 tumbuhan obat tradisional diperjualbelikan di pasar tradisonal Kabanjahe Sumatera Utara, yang digunakan sebagai bahan baku berbagai ramuan obat tradisional di lingkungan sekitar, namun disisi lain perdagangan tersebut menjadi salah satu sumber mata pencaharian sekaligus mewarisankan pegetahuan lokal. Ageratum conyzoides merupakan salah satu tumbuhan liar yang banyak dimanfaatkan sebagai obat tradisional oleh berbagai etnis di Indonesia maupun di negara lain. $\mathrm{Di}$ Indonesia, $A$. conyzoides mudah ditemukan pada lahan terganggu baik di pekarangan maupun kebun. Oleh etnis Batak, A. conyzoides dimanfaakan sebagai obat untuk mengatasi bisul dan obat demam (Silalahi 2014). Secara empirik terlihat bahwa $A$. conyzoides memiliki dua variasi bunga pita yaitu putih dan ungu, serta memiliki memiliki bau khas yang mirip dengan bau kambing sehingga namanya juga disebut sebagai tumbuhan goatweed (Bosi et al. 2013).

Pemanfaatan $A$. conyzoides sebagai obat telah banyak dilaporkan, namun kajian yang menghubungkan antara pemanfaatan dengan bioaktivitasnya masih terbatas. Artikel ini menjadi salah satu sumber untuk pemanfaatan dan rospek pengembangan $A$. 
conyzoides sebagai obat tradisional maupun obat modern.

\section{METODE PENELITIAN}

Penulisan artikel ini didasarkan pada kajian lietratur yang diperoleh secara online maupun offline meliputi berbagai artikel ilmiah kemudian dikaji dan disinteasakan sehingga meberikan informasi yang kompehensif.

\section{PEMBAHASAN}

BOTANI Ageratum conyzoides L. Ageratum conyzoides merupakan salah satu spesies yang termasuk dalam famili Asteraceae atau yang dikenal juga sebagai sembung-sembungan. Asteraceae terdiri dari sekitar 1100 genus (Conqruist 1991) hingga 1500 genus (Souza and Lorenzi, 2012) dengan jumlah spesies sekitar 20.000 (Conqruist 1991) 25.000 spesies (Souza and Lorenzi 2012) yang tersebar terutama di daerah subtropika dan berimklim sedang. Genus utama terdiri dari Senecio memiliki sekitar 1500 spesies, Vernonia terdiri dari sekitar 900 spesies, sedangkan Ageratum diperkirakan hanya terdiri dari 30 speseis (Conqruist 1991; de Padua 1999). Genus Ageratum diperkirakan memiliki sekitar 30 species (Okunade, 2002), salah satu spesiesnya Ageratum conyzoides.

$$
\text { Ageratum }
$$
conyzoides merupakan salah satu tumbuhan liar dimanfaatkan oleh berbagai etnis sebagai obat tradisional. Oleh masyarakat lokal Indonesia $A$. conyzoides memiliki nama lokal antara lain badotan, rumput tahi babi (Jambi), rumput Belanda (Bengkulu), jukut bau, ki bau (Sunda), wedusan, tempuyak (Jawa), dus bedusan (Madura), empedu tanah (Kalimantan Tengah), mbora (Kalimantan Timur), buyuk-buyuk (Manado), tada-tada (Sulawesi Tengah) (Achmad et al. 2009), siangur (Batak Angkola-Mandailing), sibaubau (Batak Toba) (Silalahi 2014). Ageratum conyzoides memiliki sinonim denga $A$. album Stend; $A$. caeruleum Hort. ex. Poir.; $A$. coeruleum Desf.; $A$. cordifolium Roxb.; A. hirsutum Lam.; A. humile Salisb.; $A$. latifolium Car.; $A$. maritimum H.B.K.; A. mexicanum Sims.; $A$. obtusifolium Lam.; $A$. odoratum Vilm. and Cacalia mentrasto Vell. (Jaccoud 1961).

$$
\text { Ageratum conyzoides }
$$

memiliki bau khas yang mirip dengan "bau kambing" sehingga namanya juga disebut sebagai tumbuhan goatweed (Bosi et al. 2013; Santos et al. 2016). Bau tersebut diduga berasal dari jaringan sekretoris yang terdapat di berbagai organ terutama tangkai dan helain daun $A$. conyzoides (Santos et al. 2016). Trikoma nonglandular terdapat pada batang dan tangkai daun sedangkan trikoma glandular hanya ada pada helaian daun (Santos et al. 2016). Tanaman ini mudah ditemukan di daerah tropis seperti Afrika, Asia dan Amerika Selatan. 
Silalahi, Ageratum Conyzoides I. (Pemanfaatan sebagai Obat dan Bioaktivitasnya)
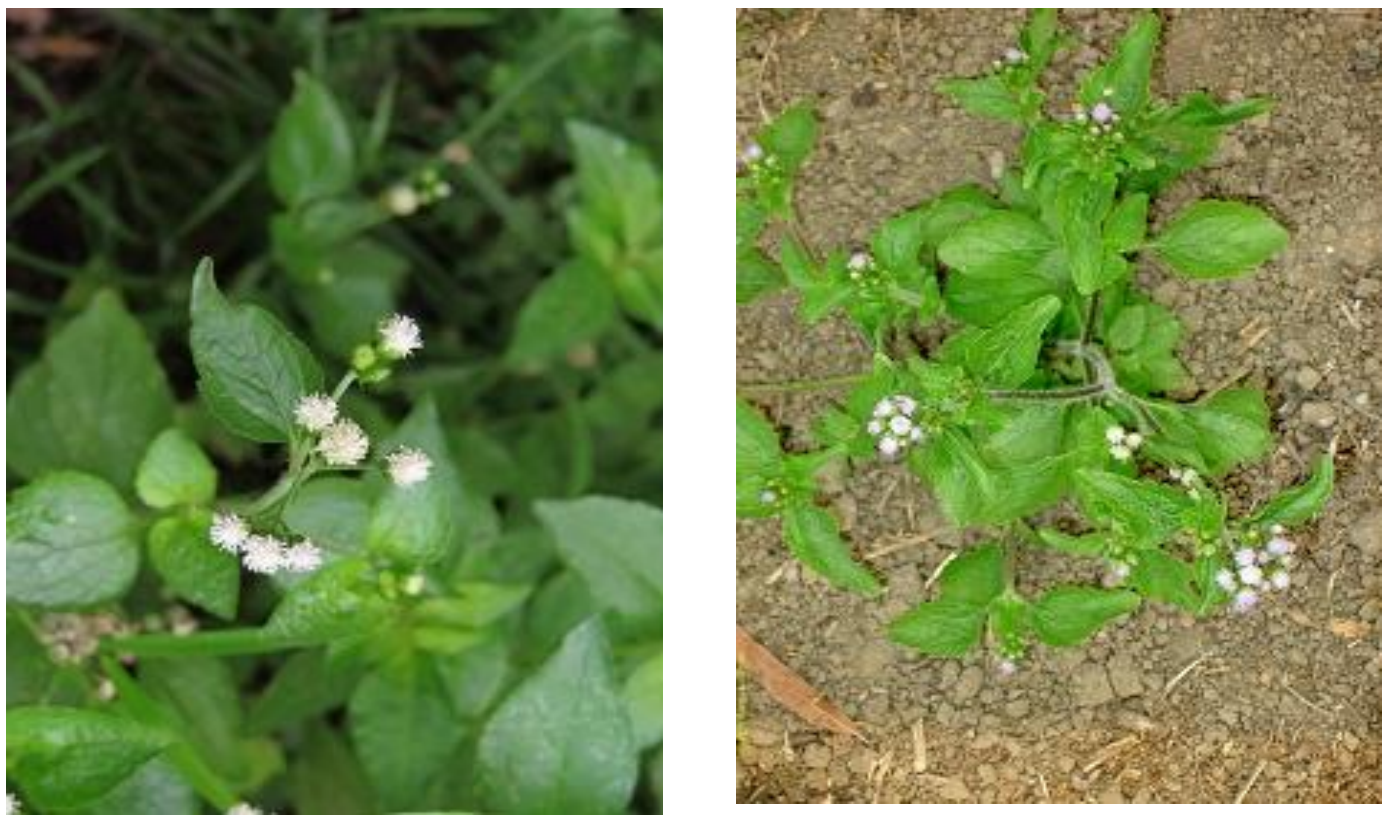

Gambar 1. Ageratum conyzoides L. atau badotan. Kiri. Berbunga putih; Kanan. Berbunga ungu
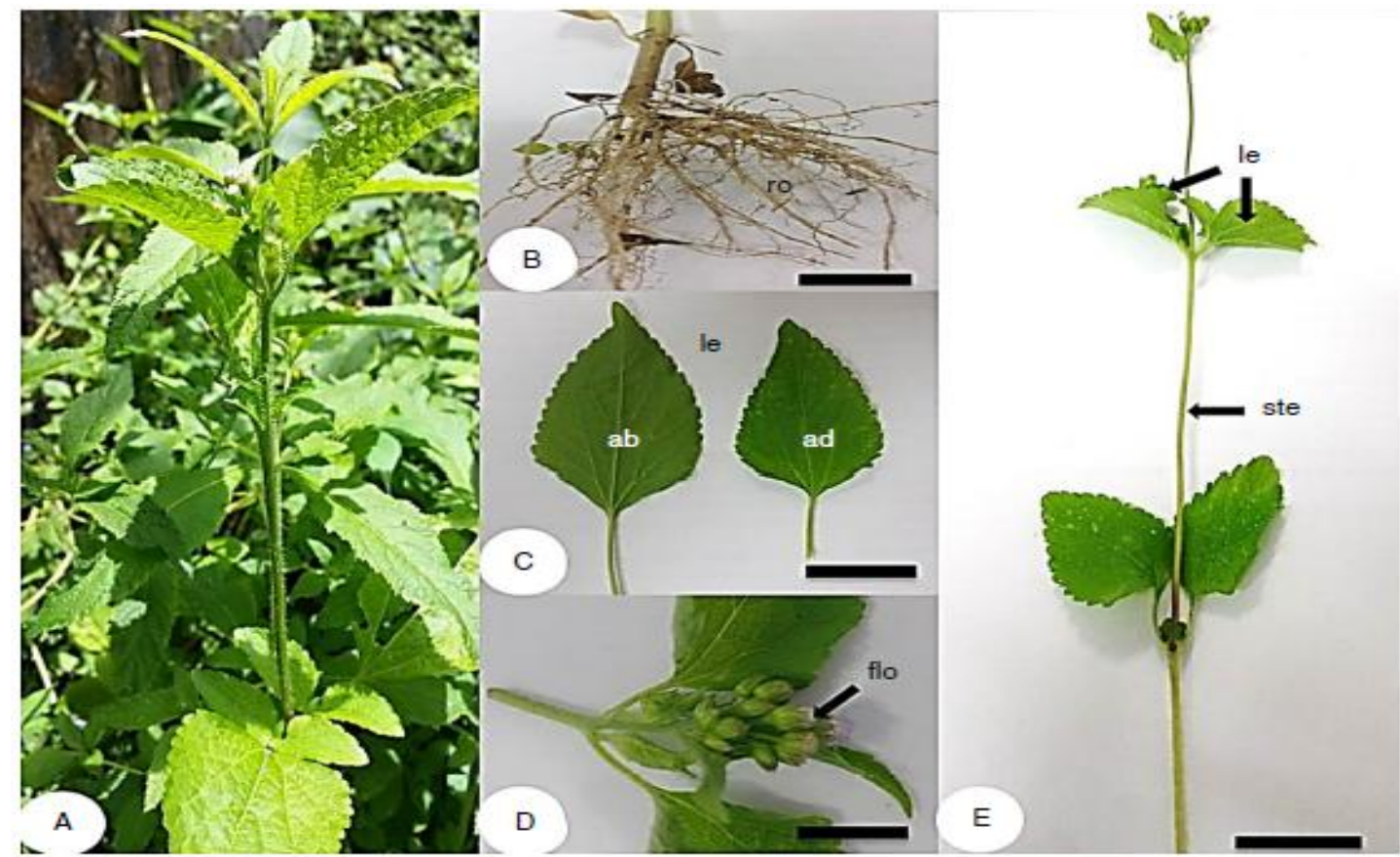

Gambar 2. Ageratum conyzoides L. (A) Habitus tanaman; (B) akar (ro); (C) daun (le), permukaan bawah daun (ab) permukaan (ad); (D) Bunga (flo); (E) Batang (ste); daun (le) (Santos et al. 2016). 

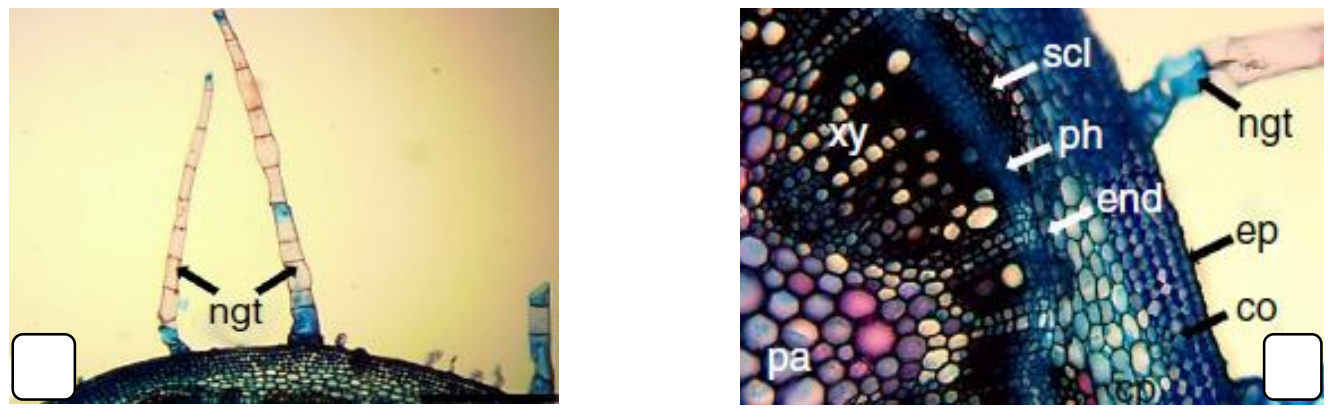

Gambar 3. Struktur anataomi dari A. conyzoides. A. trikoma yang tidak berkelenjar. B. sayatan melintang dari batang. Non-glandular trichomes (ngt), epiermis (ep) collenchyma (co)), endodermis (end), phloem (ph), xylem (xy) parenchyma (pa) (Santos et al. 2016).

SENYAWA BIOAKTIF

Tumbuhan menghasilkan berbagai metabolit sekunder maupun primer yang dapat dimanfaatkan manusia untuk berbagai tujuan termasuk dalam bidang kesehatan atau pengobatan. Metabolit sekunder yang dihasilkan tumbuhan terutama dimanfaatkan untuk obat, pewarna, dan insektisida. Dalam bidang pengobatan manusia lebih banyak memanfaatkan metabolit sekunder. Metabolit sekunder merupakan metabolit yang dihasilkan dari proses metabolisme sekunder, yang dapat memanfaatkan senyawa antara dari metabolisme primer sebagai prekusor (Taiz dan Zeiger 2006). Metabolit sekunder sebagai salah satu bentuk pertahanan terhadap cekaman lingkungan termasuk $A$. conyzoides.

Bagi masyarakat lokal Indonesia $A$. conyzoides dikenal sebagai salah satu gulma yang mudah ditemukan pada lingkungan yang terganggu seperti pekaragan, pinggir jalan, dan kebun. Secara empirik terlihat $A$. conyzoides yang ada di Indonesia memiliki dua variasi bunga yaitu bunga putih dan bunga ungu yang diduga memiliki perbedaan kandungan metabolit sekundernya. Ageratum conyzoides mengandung metabolit antara lain: terpenoid, dan flavonoid (Bosi et al. 2013), steroid, terpen, senyawa, saponin, asam lemak (Kamboj and Saluja 2011), dan alkaloid (Bosi et al. 2013; Kamboj and Saluja 2011).

Kandungan utama dari $A$. conyzoides adalah stigmasterol dan $\beta$-sitosterol (Kamboj and Saluja 2011), dan pyrrolizidine alkaloid (Bosi et al. 2013). Ekstrak air $A$. conyzoides mengandung: lycopsamine, dihydro-lycopsamine, acetyl-lycopsamine, lycopsamine $\mathrm{N}$-oxide, dihydro-lycopsamine $\mathrm{N}$ oxide, acetyl-lycopsamine $\mathrm{N}$-oxide, eupalestin, 5'-methoxynobiletin, demethoxyencecalol, encecalol, 2hydroxydihydrocinnamic acid, 2,2- 
dimethylchromane,

$3,4-$ dihydroprecocene II, 3'-hydroxy$5,6,7,8,4^{\prime}, 5^{\prime}$-hexamethoxyflavone, linderoflavone B, coumarin, precocene II, 5,6,7,3',4',5'hexamethoxyflavone,

ageconyflavone $\mathrm{C}$ (Bosi et al. 2013). Lycopsamine dan $N$-oxide dari ekstrak $A$. conyzoides memiliki aktivitas sebagai hepatotoxins dan tumorigens, sedangkan pyrrolizidine alkaloid merupakan senyawa toksin (Bosi et al. 2013). Nour et al. (2010) melaporkan kandungan flavonoid yang terdapat pada ekstrak metanol $A$. conyzoides antara lain 5,6,7,8,5pentamethoxy-3; $4-$ methylenedioxyflavone (eupalestin); 5,6,7,5-tetramethoxy3,4-methylenedioxyflavone;

$5,6,7,8,3,4,5$-heptamethoxyflavone (5-methoxynobiletine); 5,6,7,3,4,5hexamethoxyflavone; dan 4hydroxy-5,6,7,3,5pentamethoxyflavone (ageconyflavone C).

\section{MANFAAT Ageratum conyzoides} Ageratum conyzoides telah lama dimanfaatkan sebagai obat maupun sebagai insektisida, namun kajian pada artikel ini lebih difokuskan pemanfaatannya sebagai obat. Penelitian tumbuhan obat terus dilakukan untuk mecari alternatif dalam pengobatan. Berdasarkan studi etnobonatani $A$. conyzoides dimanfaatkan sebagai obat penyakit kulit, gangguan mental, penyakit infeksi (Okunade 2002), agen pencuci perut, antipiretik, anti-ulkus, dan luka
(Diallo et al. 2010), luka bakar, luka yang memiliki aktivitas sebagai antimikroba dan berbagai penyakit infeksi bakteri, arthrosis, sakit kepala dan dyspnea, pneumonia, analgesik, anti-inflammatori, antiasthmatic, anti-spasmodic dan efek hemostatik, penyakit perut, penyakit ginekologi, lepra dan penyakit kulit lainnya (Kamboj and Saluja 2008). Walaupun $A$. conyzoides digunakan secara tradisional untuk mengatsai berbagai jenis penyakit, namun yang telah diuji secara ilmiah antara lain: obat asam, obat diabetes mellitus, antioksidan, anti mikroba, sitoprotektif, analgesik, antiplasmodial, dan obat luka.

OBAT ASMA

Asma merupakan salah satu penyakit yang diakibatkan gannguan pernafasan, yang mengakibatkan penderita sulit bernapas karena adanya penyempitan saluran pernafasan. Secara empirik terlihat bahwa obat yang digunakan untuk penderita asma adalah anti histamin. Pemanfatan $A$. conyzoides sebagai obat asma karena dapat menginduksi relaksasi trakea telah dilaporkan oleh Achola dan Munenge (1998). Ektraks $A$. conyzoides memiliki aktivitas untuk melawan aktivitas 5hydroxytryptamine (5-HT) dan histamin yang diisolasi dari trakea dan menghamabat aktivitas 5-HT sebesar $79 \%$ dan histamin sebesar 86\% (Achola and Munenge 1998). ANTI MIKROBA 
Berbagai penyakit dikaitkan dengan infeksi mikroba yang bersifat patogen maupun yang menyebabkan keracnan makanan. Pertumbuhan mikroba dihambat dengan cara merusak komponen sel mikroba atau menghambat sintesa DNA. Hasil penelitian menunjukkan bahwa $A$. conyzoides menghambat pertumbuhan Staphylococcus aureus (Akinyemi et al. 2005). Minimum inhibition concentration dari ekstrak air dan etanol dari $A$. conyzoides sebesar $55,4 \quad$ - $71,0 \quad \mathrm{mcg} / \mathrm{ml}$ terhadap Staphylococcus aureus (Akinyemi et al. 2005).

\section{ANTIOKSIDAN}

Senyawa yang digunakan atau berpotensi sebagai antioksidan merupakan senyawa yang menghambat radikal bebas. Potensi sebagai antioksidan dari ekstrak metanol batang Ageratum conyzoides diukur dengan menggunakan aktivitas DPPH scavenging, mengurangi kemampuan, kapasitas antioksidan total serta total fenolik. Persentase (\%) pembilasan DPPH radikal bebas dari ekstrak ditemukan konsentrasi tergantung dengan nilai IC50 46,01 $\pm 2,23 \mu \mathrm{\mu g} / \mathrm{ml}$ sedangkan nilai IC50 asam askorbat standar ditemukan menjadi 29,56 $\pm 0,11 \mu \mathrm{g} / \mathrm{ml}$. Daya reduksi antioksidan ditemukan tergantung konsentrasi. Sitotoksisitas yang ditunjukkan oleh antioksidan ditemukan menjanjikan dengan nilai LC50 $1,32 \mu \mathrm{g} / \mathrm{ml}$, dibandingkan dengan nilai $\operatorname{LC50}(0,689 \mu \mathrm{gg} / \mathrm{ml}) \quad$ dari vincristin sulfat. Penyelidikan saat ini menunjukkan bahwa $A$. conyzoides memiliki sifat antioksidan dan sitotoksik yang luar biasa (Nasrin et al. 2013). OBAT LUKA

Berbagai aktivitas manusia mengakibatkanya luka pada kulit dan merupakan salah satu jalan masuk berbagai mikroba patogen terhadap luka. Hasil penelitian menunjukkan bahwa ekstrak $A$. conyzoides memiliki aktivitas sebagai anti luka, karena merangsang pembentukan jaringan ikat berupa jaringan fibroblas. Ekstrak metanol dari $A$. conyzoides diberikan pada sebayak 20 hewan percobaan dibagi menjadi dua kelompok sebagai kontrol dan percobaan. Setiap hewan diberi luka seluas $2 \mathrm{~cm} \times 2 \mathrm{~cm}$ pada kulit disisi kanan dorsoventral. Peningkatan yang signifikan dalam persentase kontraksi luka pada hari ke-10 pada kelompok eksperimen dibandingkan dengan kontrol $(82,3 \pm 1,6 \%$ vs $55,0 \pm$ 4,2\%) (Oladejo et al. 2003).

Ekstrak akar $A$. conyzoides memiliki aktivitas untuk penyembuhan luka (Sachin et al. 2009), namum poliherbal yang terdiri dari $A$. conyzoides, Ficus religiosa, Curcuma longa and Tamarindus indica, memiliki aktiviats yang lebih tinggi dibandingkan dengan ekstrak tunggal $A$. conyzoides pada tikus (Sachin et al. 2009). Ageratum conyzoides mengandung senyawa bioaktif berupa pyrrolizidine alkaloids dan polymethoxyflavones 
(Galati et al. 2001). Flavonoid menunjukkan aktivitas antiinflamasi (Galati et al. 2001).

OBAT DIABETES MELLITUS Secara umum tumbuhan yang digunakan oleh masyarakat lokal sebagai obat diabetes mellitus merupakan tumbuhan yang memiliki rasa pahit (Silalahi 2015a). Hal tersebut didasarkan bahwa diabetes mellitus mellitus dihubungkan dengan kelebihan kadar "gula" di dalam tubuh, oleh karena itu dibutuhkan senyawa pahit untuk menetralkannya. Walaupun demikian tidak semua tumbuhan yang memiliki bersifat anti diabetes (de Padua et al. 1999). Wiryodidagdo et al. (2000) menyatakan bahwa tumbuhan utama berkhasiat sebagai obat penyakit diabetes mellitus merupakan tumbuhan yang menghasilkan senyawa yang mampu menekan atau merangsang kerja kelenjar endokrin, sehingga dapat memengaruhi produksi hormon dan mengubah proses fisiologi organ tubuh.

Ekstrak air $A$. conyzoides telah terbukti memiliki sifat hipoglikemik dan anti hiperglikemik pada tikus percobaan. Tikus yang diuji diberi ekstrak air dari $A$. conyzoides pada dosis 100, 200, dan $300 \mathrm{mg} / \mathrm{kg}$ menunjukkan signifikan secara statistik menunjukkan aktivitas hipoglikemik dan antihiperglikemik. Untuk tes toleransi glukosa oral, hanya dosis $100 \mathrm{mg} / \mathrm{kg}$ dilemahkan secara signifikan kenaikan glukosa darah pada tikus berpuasa normal (Nyunaï et al. 2009). Hal yang hampir sama juga dilaporkan oleh (Agunbiade et al. 2012) bahwa hewan diabetes yang diinduksi aloksan diberikan $500 \mathrm{mg} / \mathrm{kg}$ berat badan ekstrak air dari $A$. conyzoides dan glibenclamide sebagai agen referensi hipoglikemik. Ekstrak air dari $A$. conyzoides mengurangi glukosa darah puasa hewan percobaan sebesar 39,1\% (Agunbiade et al. 2012).

Pemberian ekstrak daun $A$. conyzoides hingga $5000 \mathrm{mg} / \mathrm{kg}$ diberikan kepada tikus Wistar dan kemudian diamati secara individual 1 jam setelah pemberian dosis, dan setidaknya sekali sehari selama 14 hari. Hasil penelitian menunjukkan bahwa hingga dosis batas $5000 \mathrm{mg} / \mathrm{kg}$ ekstrak daun $A$. conyzoides tidak menyebabkan kematian atau tanda-tanda toksisitas akut pada tikus diuji selama periode observasi. Hal tersebut menunjukkan bahwa ekstrak hidroalkohol $A$. conyzoides relatif aman ketika diberikan secara oral pada tikus (Diallo et al. 2010). Uji bioasai dilakukan pada tikus diabetes yang disebabkan oleh streptozotocin (STZ). Essensial oil dari $A$. conyzoides memiliki potensi anti hiperglikemik dan mengandung lebih dari satu senyawa anti hiperglikemik dengan karakteristik kimia dan mekanisme aksi yang berbeda (Nyunaï et al. 2010).

SITOPROTEKTIF 
Berbagai makanan dan minuman yang dikosumsi dapat berdampak negatif terhadap jaringan lambung terutama alkohol. Mahmood et al. (2005) menyatakan bahwa ekstrak air daun $A$. conyzoides memiliki aktivitas sebagai sitoprotektif (perlindungan sel) untuk melawan lesi lambung yang diinduksi alkohol pada tikus. Empat kelompok tikus Sprague Dawley jantan yang masing masing enam ekor hewan yaitu kelompok I diberi dengan fosfat buffer saline $5 \mathrm{~mL} / \mathrm{kg}$ sebagai kontrol dan kelompok II dan III diberi dengan $250 \mathrm{mg} / \mathrm{kg}$ dan 500 $\mathrm{mg} / \mathrm{kg}$ ekstrak $A$. conyzoides (5 $\mathrm{mL} / \mathrm{kg}$ ) secara berturut-turut, sedangkan kelompok IV diberi dengan cimitide $50 \mathrm{mg} / \mathrm{kg}$ sebagai referensi. Secara maksroskopis pemberian etanol mengakibatkan lesi hemorrhagic pada jaringan mukosa lambung, sebaliknya dengan pemberian $250-500 \mathrm{mg} / \mathrm{kg}$ ektrak air dan cimitidine secara signifikan menurunkan lesi lambung dibandingkan dengan kontrol. Secara mikroskopis pemberian ekstrak air $A$. conyzoides dan cimitidine menunjukkan penghambatan lesi lambung dan ditandai dengan reduksi edema submukosa dibandingkan dengan kontrol (Mahmood et al. 2005).

\section{ANTIPLASMODIAL}

Malaria merupakan salah satu penyakit menular yang disebabkan oleh Plasmodium spp. dengan perantraaan nyamuk, umumnya banyak ditemukan di daerah tropis termasuk Indonesia. Kina (Chinchona ledgeriana) yang menghasilkan kuinin merupakan tumbuhan yang telah lama dikenal sebagai obat malaria (Ukwe et al. 2010). Berbagai fakta menunjukkan bahwa Plasmodium meningkatkan resistensinya terhadap berbagai senyawa kimia anti malaria. Untuk itu penelitian tumbuhan sebagai anti malaria terus dilakukan termasuk $A$. conyzoides. Silalahi (2014) menyatakan bahwa etnis Batak Sumatera Utara juga memanfatkan tumbuhan yang sangat pahit untuk mengatasi malaria termasuk di dalamnya $A$. conyzoides. Daun $A$. conyzoides yang diesktrak dengan menggunakan air, metanol dan nhexana memiliki aktivitas sebagai antiplasmodial sehingga dapat digunakan sebagi obat malaria. Aktivitas anti plasmodial dari ekstrak air dan metanol secara invivo diuji pada tikus yang terinfeksi Plasmodium berghei selama 4 hari. Semua ekstrak $A$. conyzoides menunjukkan aktivitas antiplasmodial yang signifikan ( $\mathrm{p}$ $<0,05$ ), namun efektivitasnya tergantung dosis (Ukwe et al. 2010).

\section{OBAT PENYAKIT TIDUR}

Penyakit tidur merupakan salah satu panyakit yang disebabkan oleh protozoa dari golongan Trypanosoma. Ekstrak diklorometana $A$. conyzoides menunjukkan aktivitas (IC50 $=0,78$ $\mu \mathrm{g} / \mathrm{mL}$ ) terhadap bentuk aliran darah Trypanosoma brucei rhodesiense (agen penyakit tidur di 
Afrika Timur). Ekstrak ini juga menunjukkan aktivitas nyata terhadap Leishmania donovani $(\mathrm{IC50}=3,4 \mu \mathrm{g} / \mathrm{mL})$ serta Plasmodium falciparum (Malaria tropica IC50 = 8,0 $\mu \mathrm{g} / \mathrm{mL}$ ) (Nour et al. 2010).

\section{ANALGESIK}

Senyawa analgesik merupakan senyawa yang berfungsi untuk mengurangi rasa sakit. Pemanfaatan $A$. conyzoides sebagai analgesik telah dilaporkan oleh (Rahman et al. 2012). Ekstrak alkohol daun $A$. conyzoides dan Emilia sonchifolia memiliki aktivitas untuk mengurangi rasa sakit, namun responnya tergantung dosis. Ekstrak alkohol dari daun $A$. conyzoides memiliki kemampuan mengurangi rasa sakit yang lebih tinggi dibandingkan dengan Emilia sonchifolia yaitu sebesar $49,85 \%$ dan $39,47 \%$. Efek ekstrak $A$. conyzoides memiliki efek yang signifikan $(P \quad<0,05) \quad$ untuk mengurangi rasa sakit dibandingkan natrium diklofenak (40 mg/kg). Ekstrak A. conyzoides mengurangi rasa sakit sebesar $35,48 \%$ pada rasa nyeri yang diinduksi dengan formalin $2,0 \mathrm{~g} / \mathrm{kg}$ dan dengan morfin $(0,5 \mathrm{mg} / \mathrm{kg})$ (Rahman et al. 2012). Ekstrak A. conyzoides mengandung metabolit sekunder khususnya flavonoid (Moreira et al. 2007) memiliki aktivitas sebagai analgesik dengan target utama prostaglandins (Rajnarayana et al. 2001). Kemampuan untuk mengurangi rasa sakit diduga berhubungan dengan kemampuan ekstrak $A$. conyzoides memblok nerromuscular (Achola and Munenge 1997). Ekstrak $A$. conyzoides memiliki aktivitas memblokir saluran kalsium mirip dengan verapamil (Achola and Munenge 1997).

\section{KESIMPULAN}

1. Ageratum conyzoides mengandung metabolit sekunder dari golongan terpenoid, flavonoid, steroid, terpen, senyawa, saponin, asam lemak, dan alkaloid, dengan senyawa utama stigmasterol dan $\beta$-sitosterol

2. Ageratum conyzoides dalam pengobatan tradisonal dimanfaatkan sebagai obat luka, bisul, dan demam. Bioaktivitas yang dimiliki oleh $A$. conyzoides antara lain sebagai anti histamin, antimikroba, antiplasmodial, sitoprotektif, analgesik, antioksidan dan anti diabetes mellitus.

\section{ACUAN PUSTAKA}

Achmad, S.J., Syah, Y.M., Hakim, E.H., Juliawaty, L.D., Makmur, L., \& Mujahidin, D. (2008). IImu Kimia dan Kegunaan TumbuhTumbuhan Obat Indonesia. Institut Teknologi Bandung, Bandung, viii + $350 \mathrm{hlm}$.

Achola, K.J. \& Munenge, R.W. (1998). Bronchodilating and uterine activities of Ageratum conyzoides extract. Pharmaceutical Biology 36(2): 93-96.

Adebayo, A.H., Zeng, G.Z., Zhang, Y.M., Ji, C.J., Akindahunsi, 
A.A., \& Tan, N.H. 2010. Toxicological evaluation of precocene II isolated from Ageratum conyzoides L. (Asteraceae) in Sprague Dawley rats. African Journal of Biotechnology 9(20): 29382944.

Agunbiade, O.S., Ojezele, O.M., Ojezele, J.O., \& Ajayi, A.Y. (2012). Hypoglycaemic activity of Commelina africana and Ageratum conyzoides in relation to their mineral composition. African Health Sciences 12(2): 198-203.

Akinyemi, K.O., Oladapo, O., Okwara, C.E., Ibe, C.C., \& Fasure, K.A. (2005). Screening of crude extracts of six medicinal plants used in SouthWest Nigerian unorthodox medicine for anti-methicillin resistant Staphylococcus aureus activity. BMC Complementary and Alternative Medicine 5(6): 1-7.

Bosi, C.F., Rosa, D.W., Grougnet, R., Lemonakis, N., Halabalaki, M., Skaltsounis, A.L., \& Biavatti, M.W. (2013). Pyrrolizidine alkaloids in medicinal tea of Ageratum conyzoides. Brazilian Journal of Pharmacognosy 23(3): 425-432.

Conqruist, A. (1981). An Integrated Sysytem of Clasification of Flower Plants. Columbia University Press, New York.

$\mathrm{De}$ Padua, L.S., Bunyapraphatsara, \& R.H.M.J. Lemmens.(1999). Plants Resources of South-East Asia
No 12(1). Backhuys Publishers, Leiden.

Diallo, A., Eklu-Gadegkeku, K., Agbonon, A., Aklikokou, K., Creppy, E.E. \& Gbeassor, M. (2010). Acute and sub-chronic (28-day) oral toxicity studies of hydroalcohol leaf extract of Ageratum conyzoides L (Asteraceae). Tropical Journal of Pharmaceutical Research 9(5): 463-467.

Galati, E.M., Miceli, N., Taviano, M.F., Sanogo, R., \& Raneri, E. (2001) Antiinflammatory and antioxidant activity of Ageratum conyzoides. Pharmaceutical Biology 39(5): 336-339.

González, A.G., Aguiar, Z.E., Grillo, T.A., Luis, J.G., Rivera, A., \& Calle, J. (1991). Chromenes from Ageratum conyzoides. Phytochemistry 30: 1137-1139.

Herz, W. \& Kulanthaivel, P. (1982). Flavones from Eupatorium leucolepis. Phytochemistry 21: 2363-2366.

Jaccoud, R.J.S. (1961). Contribuição para o estudo formacognóstico do Ageratum conyzoides L. Rev. Bras. Farm. 42(11/12): 177-197.

Kamboj, A. \& Saluja, A.K. (2011). Isolation of stigmasterol and $\beta$ sitosterol from petroleum ether extract of aerial parts of Ageratum conyzoides (Asteraceae). International Journal of Pharmacy and Pharmaceutical Sciences 3(1): 94-96. 
Silalahi, Ageratum Conyzoides I. (Pemanfaatan sebagai Obat dan Bioaktivitasnya)

Kohler, J.C. \& Baghdadi-Sabeti, G. 2011. The World Medicines Situation, $3^{\text {rd }}$ Ed, World Health Organization.

Kupriyanova, G. (1997). NMR studies of the electronic structure of coumarins. J Struct Chem 38: 408-414.

Mahmood, A.A., Sidik, K., Salmah, I., Suzainur, K.A.R., \& Phili, K. (2005). Antiulcarogenic activity of Ageratum conyzoides leaf extract against ethanol-induces gastric ulcer in rat as animal model. International Journal of Molecular Medicine and Advance Sciences 1(4): 402405.

Moazzami, A.A., Andersson, R.E., \& Kamal-Eldin, A. (2007). Quantitative NMR analysis of a sesamin catechol metabolite in human urine. J. Nutr. 137: 940944.

Nasrin, F. (2013). Antioxidant and cytotoxic activities of Ageratum conyzoides stems. International Current Pharmaceutical Journal 2(2): 33-37.

Noura, A.M.M., Khalid, S.A., Kaiser, M., Brun, R., Abdalla, W.E., \& Schmidt, T.J. (2010). The antiprotozoal activity of methylated flavonoids from Ageratum conyzoides L. Journal of Ethnopharmacology 129: 127-130.

Nyunaï, N., Njikama, N., Abdennebic, E.H., Mbaford, J.T., \& Lamnaouer, D. (2009). Hypoglycaemic and antihyperglycaemic activity of Ageratum conyzoides L. in rats.
Afr. J. Trad. CAM. 6(2): 123130.

Okunade, A.L. (2002). Ageratum conyzoides L. (Asteraceae). Fitoterapia 73: 1-16.

Oladejo, O.W., Imosemi I.O., Osuagwu, F.C., Oluwadara, O.O., Aiku, A., Adewoyin, O., Ekpo, O.E, Oyedele, O.O., \& Akang, E.E.U. (2003). Enhancement of cutaneous wound healing by methanolic extracts of Ageratum conyzoides in the wistar rat. African Journal of Biomedical Research 6(1): 27-31.

Sachin, J., Neetesh, J., Tiwari, A., Balekar, N., \& Jain, D.K. (2009). Simple evaluation of wound healing activity of polyherbal formulation of roots of Ageratum conyzoides Linn. Asian J. Research Chem. 2(2):135-138.

Santos, R.F., Nunes, B.M., Sá, R.D., Soares, L.A.L., \& Randau, K.P. (2016). Morphoanatomical study of Ageratum conyzoides. Revista Brasileira de Farmacognosia 26: 679-687.

Silalahi, M. (2014). The ethnomedicine of the medicinal plants in sub-ethnic Batak, North Sumatra and the conservation perspective, dissertation. Indonesia: Universitas Indonesia.

Silalahi, M., Nisyawati, Walujo, E.B., Supriatna, J., \& Mangunwardoyo, W. (2015). The local knowledge of medicinal plants trader and diversity of medicinal plants in 
JDP Volume 11, Nomor 3, November 2018: 197-209

the Kabanjahe traditional market, North Sumatra, Indonesia. Journal of Ethnopharmacology 175: 432443.

Taiz, L. \& Zeiger, E. (2006). Plant Physiology. Sinauer Associates, Inc, Sunderland: xxvi + $764 \mathrm{hlm}$. Ukwe, V.C., Epueke, E.A., Ekwunife, O.I., Okoye, T.C., Akudor, G.C., \& Ubaka, C.M. (2010). Antimalarial activity of aqueous extract and fractions of leaves of Ageratum conyzoides in mice infected with Plasmodium berghei. International Journal of Pharmaceutical Sciences 2(1): 33-38.

Wiryowidagdo, S. (2000). Kimia dan Farmakologi Bahan Alam Edisi I. Direktorat Pembinaan Pengabdian Pada Masyarakat Direktorat Jenderal Pendidikan Tinggi Departemen Pendidikan Nasional, Jakarta. 